\title{
Reuse of Waste Plastics in Developing Countries: Properties of Waste Plastic-Sand Composites
}

\author{
Alexander Kumi-Larbi Jnr ${ }^{1}\left[\right.$ ] Richard Galpin ${ }^{1} \cdot$ Silva Manjula $^{2} \cdot$ Zoe Lenkiewicz $^{3} \cdot$ Christopher Cheeseman $^{1}$
}

Received: 28 September 2021 / Accepted: 31 January 2022 / Published online: 14 February 2022

(c) The Author(s) 2022

\begin{abstract}
Waste plastics are a major problem in developing countries, where efficient collection and recycling systems often do not exist. Plastic bonded sand composites provide a low-cost recycling alternative for selected waste plastics. This research has investigated the production and properties of plastic bonded sand manufactured using low-density and high-density polyethylene (LDPE and HDPE). Plastic bonded sand production in The Gambia was used as a case study to identify potential barriers to the technology. Processing was done by oven moulding, or a heat-mixing technique, and the properties of the LDPE and HDPE bonded sand samples formed have been determined. Processing at temperatures between $250{ }^{\circ} \mathrm{C}$ and $325^{\circ} \mathrm{C}$ produced optimum compressive and flexural strengths. Higher processing temperatures reduced strength and lower temperatures produced inhomogeneous samples. Thermal plastic degradation occurs at $400{ }^{\circ} \mathrm{C}$ in $\mathrm{N}_{2}$ and $250{ }^{\circ} \mathrm{C}$ in air. Processing at temperatures below $250^{\circ} \mathrm{C}$ in anoxic conditions is necessary to control off-gases. The optimum sand addition to produce the highest compressive strength was between 65 and 80\%, depending on the sand particle size. HDPE produced higher maximum compressive strengths (37.1 MPa) compared to LDPE (27.2 MPa). Plastic bonded sand has increased strength, toughness, ductility, and thermal conductivity compared to C20/25 concrete and sandcrete and it can be used for wall construction blocks and paving tiles. The potential applications and implications of processing waste plastics in developing countries into plastic bonded sand are discussed.
\end{abstract}

\section{Graphical Abstract}

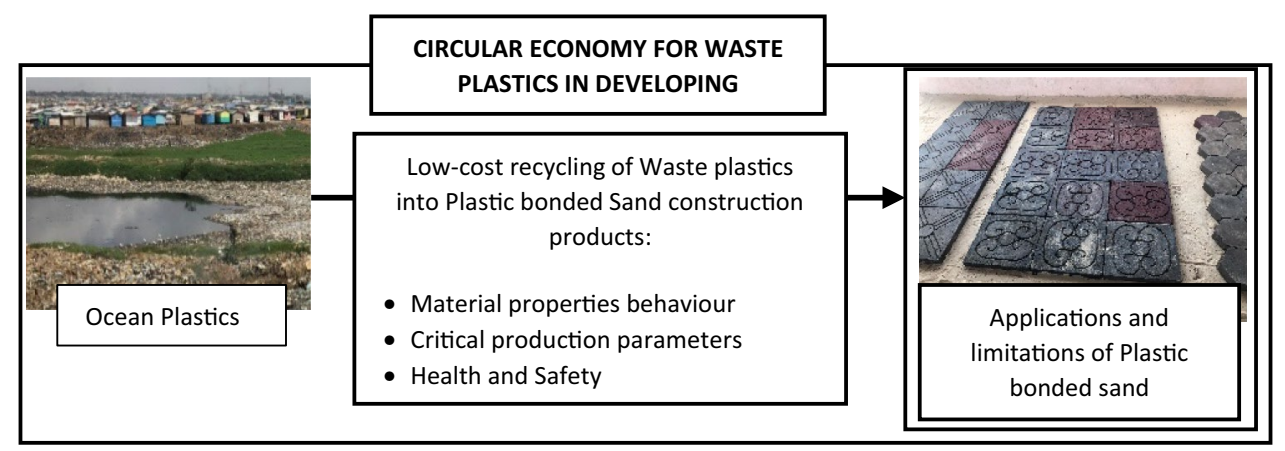

Keywords Circular economy $\cdot$ Ocean plastics $\cdot$ Sustainable development $\cdot$ Waste plastic recycling

Alexander Kumi-Larbi Jnr

alexander.kumi-larbi-jnr16@imperial.ac.uk

1 UKCRIC Advanced Infrastructure Materials Laboratory, Department of Civil and Environmental Engineering, Imperial College London, London SW7 2BU, UK

2 Department of Materials, Imperial College London, London SW7 2AZ, UK

3 Waste Aid UK, Wye, Kent, UK

\section{Statement of Novelty}

Low-cost recycling solutions are needed to address ocean plastics from developing countries (DCs). Waste plastics are being used as a binder to produce lightweight construction products including paving and roof tiles in DCs to enhance recycling efforts. However, there is no comprehensive data 
or clear understanding on the material behaviour of plastic bonded sand. This research gap has hindered its wide scale application despite its huge potential to enhance recycling efforts and provide jobs in DCs. The comprehensive primary data on the properties and health and safety concerns of plastic bonded sand provided in this work reveals the suitable applications and limitations of the novel technology. The findings underpin the development of a new value chain for waste plastics in DCs.

\section{Introduction}

Despite significant improvements in global recycling rates, less than $20 \%$ of waste plastics are properly managed [1]. Improper plastic disposal causes environmental problems with ocean plastics now recognised as a major global issue $[2,3]$. It is estimated that $80 \%$ of ocean plastics come from coastal developing countries (DCs) where inadequate plastic waste management systems result in indiscriminate dumping of plastics into water bodies [4]. A typical example from Ghana is shown in Fig. 1. Improperly managed waste plastics block drainage systems and waterways, increasing the risk of flooding and stagnant water and this can have a serious deleterious effect on public health.

Low-cost plastic recycling technologies that produce aggregates and fibres for use in lightweight concrete and flexible pavements exists [5-9]. Concrete containing polyethylene aggregate have improved flexibility and toughness [10]. High performance flexible pavements have been produced from waste plastic modified asphalt with reduced costs [11-17]. PET has been used to replace 20 wt.\% of aggregate in low-density asphalt [18]. Flexible pavements have been produced with $30 \mathrm{wt}$.\% of the aggregate replaced by LDPE [19].

A toolkit has been developed by WasteAid UK to train local communities in DCs on how to produce plastic bonded sand using ubiquitous single-use packaging plastics [20]. The innovative use of plastic bonded sand in paving blocks, tiles, advertisement poles and construction panels for affordable housing is ongoing in many countries including Kenya, Columbia, Cameroon, Uganda, The Gambia and Ghana. These types of recycling applications provide local employment opportunities and ensure a circular economy for selected waste plastics [21-24]. However, there is limited research on the use of waste plastics, particularly LDPE and HDPE, to produce plastic bonded sand. Further understanding of the effect of temperature on the processing and properties of different compositions of plastic bonded sand is required. This research reports on how processing conditions and composition influence the gases generated during processing and the properties of plastic bonded sand. The influence of processing temperature, sand addition level and sand particle size on the compressive strength and flexural strength of LDPE and HDPE based plastic bonded sand are reported. The potential for these materials to provide a solution to the plastic waste problem in DCs is discussed.

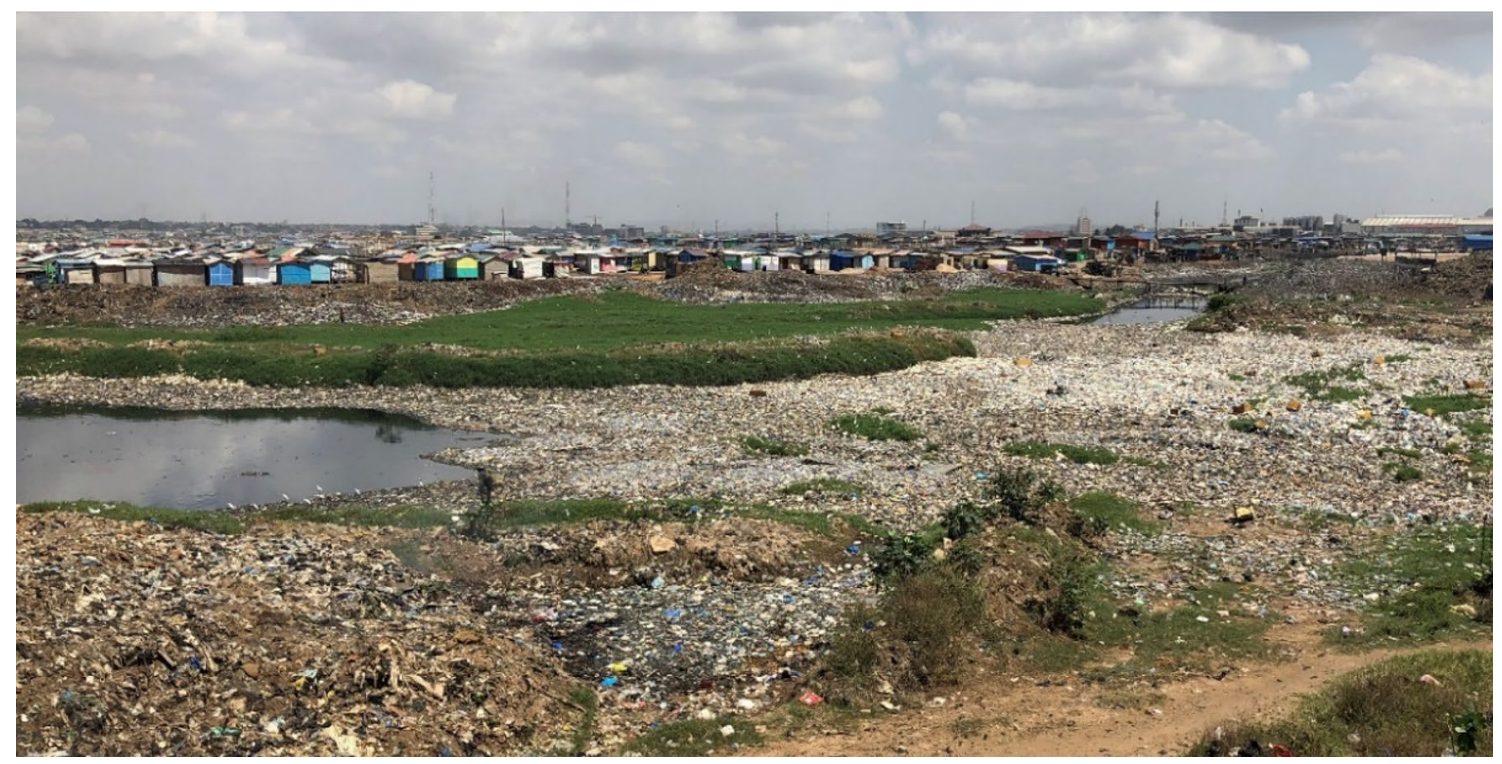

Fig. 1 Indiscriminate dumping of plastic waste into the Korle Lagoon in Accra, Ghana 


\section{Case Study of Plastic Bonded Sand Production in the Gambia}

Plastic bonded sand production in Gunjur, The Gambia was studied in June 2019 to understand how these materials are produced in the field and identify the barriers to more widespread use of the production process. The study was conducted in collaboration with WasteAid UK and involved 90 Gunjur residents collecting, sorting, and processing plastic waste into plastic bonded sand products. $800 \mathrm{~kg}$ of LDPE was processed each week into roofing and paving tiles and these were used to pave local businesses' premises.

Waste plastics were collected from households and waste dumps. The informal waste collectors can recover $\sim 80 \%$ of valuable recyclables from municipal solid waste using simple sorting techniques [25]. LDPE was separated from the waste using the recycling number on containers (4 for LDPE) and simple flame and stretching tests, as shown in Fig. 2a. LDPE produces a blue flame when ignited and has greater flexibility and ductility than other plastics. Local construction sand was used as the filler. The sorted LDPE and sand were sun-dried prior to processing and firewood was used as fuel. Although firewood is ubiquitous in Gunjur, a more efficient fuel source is recommended for the process.

The required quantity of LDPE was heated in a locally fabricated metallic steel drum preheated to about $150{ }^{\circ} \mathrm{C}$. The LDPE was then further heated until it melted at temperatures between 220 to $420{ }^{\circ} \mathrm{C}$ as shown in Fig. 2b. Sand was then mixed into the molten LDPE, until a homogenous

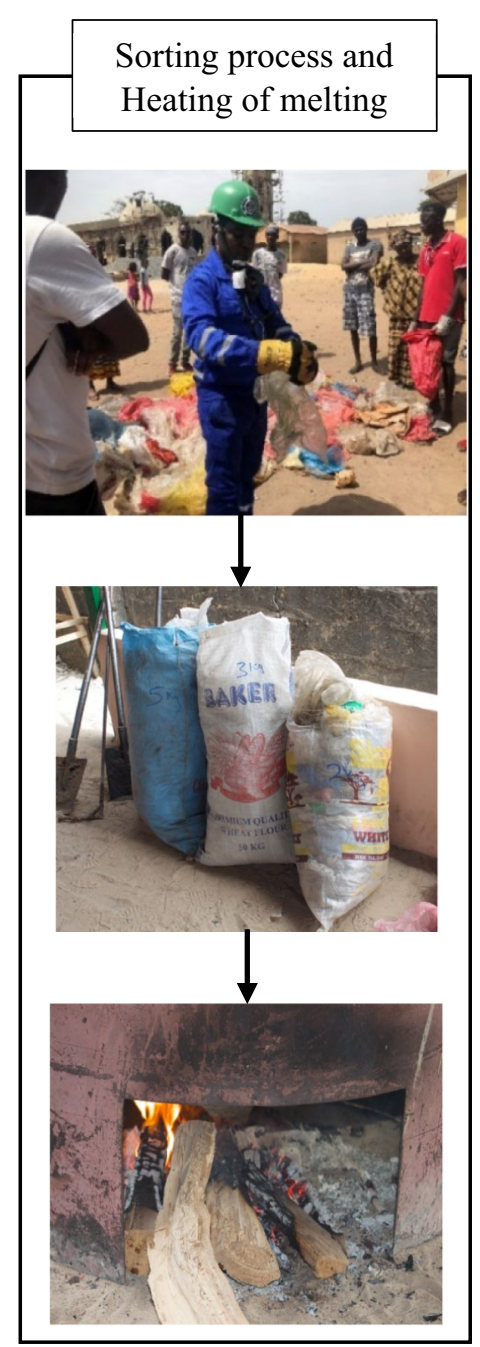

(a)

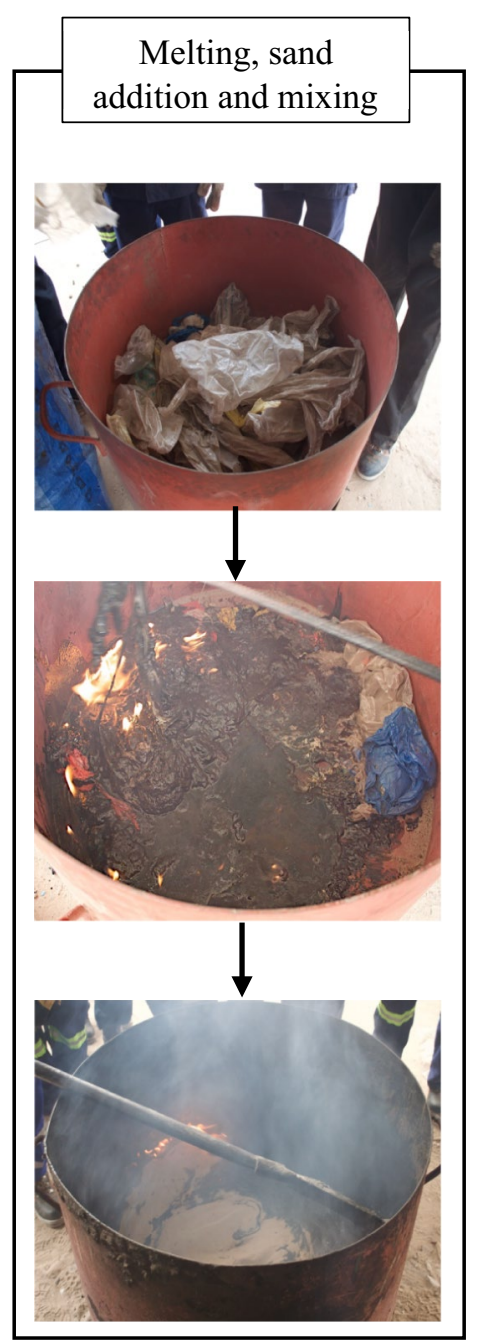

(b)

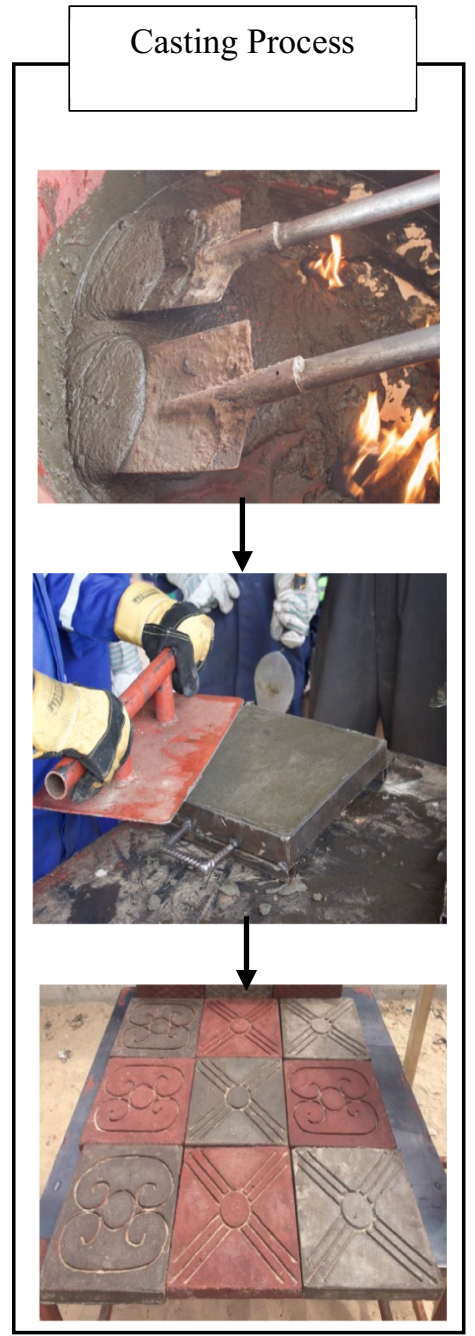

(c)

Fig. 2 Plastic bonded sand production in The Gambia. The process involves sorting and melting LDPE waste plastics, mixing of sand into molten plastics and casting into steel moulds to form plastic bonded sand paving tiles 
dough-like paste was formed. This was then cast into steel moulds, pre-coated with palm oil, to form plastic bonded sand paving and roofing tiles as shown in Fig. 2c. The temperature of the paste before casting was between 200 and $210{ }^{\circ} \mathrm{C}$. All temperature measurements were recorded using an infrared thermometer.

Those involved in the processing wore gas masks, fire retardant overalls, safety boots, heat-proof gloves, and safety glasses to minimise the risk of exposure to off-gases. The plastics often ignited during melting and produced smoke as shown in Fig. 2b. The smoke may contain hazardous compounds that pose a health risk to the workers [26-28]. Potential health impacts of the compounds may include sensory effects, target organ damage, nervous system and respiratory effects [29]. Work exposure limits for selected compounds produced during the thermal processing of polyethylene at $>325{ }^{\circ} \mathrm{C}$ are shown in Table 1 [30-32]. The resin type, residual monomer content, degree of stabilization and the presence of additives influence the characteristics of the VOCs emitted. Additives and UV stabilizers present in processed plastics such as dibutyl hydroxytoluene volatilize at processing temperatures $>265{ }^{\circ} \mathrm{C}$ [33]. Key field observations that formed the basis for the experiments in this research included:

- The release of smoke and off-gases due to processing at uncontrolled temperatures

- The effect of varying processing temperature on the plastic bonded sand properties

- The effect of sand addition and particle size on plastic bonded sand properties.

\section{Materials and Methods}

Polyethylene $\left(\mathrm{C}_{2} \mathrm{H}_{4}\right)_{\mathrm{n}}$ is a non-polar polymer with no functional groups attached to the carbon backbone and is categorised into low-density polyethylene (LDPE) and high-density polyethylene (HDPE). LDPE has high ductility with densities between 0.91 and $0.94 \mathrm{~g} \mathrm{~cm}^{-3}$ and crystallinity between 35 and $55 \%$. HDPE has a density greater than $0.94 \mathrm{~g} \mathrm{~cm}^{-3}$ with higher crystallinity, strength and stiffness compared to

Table 1 EH40/2005 workplace exposure limits and GHS hazard classes and categories for compounds identified in off-gases at LDPE processing workshops $[30,34]$

\begin{tabular}{|c|c|c|c|c|c|c|c|c|c|c|c|c|c|}
\hline \multirow[t]{2}{*}{ Compound } & \multicolumn{2}{|c|}{ Work exposure limit } & \multirow[b]{2}{*}{$\begin{array}{l}224 \\
225 \\
226\end{array}$} & \multicolumn{10}{|c|}{ Hazard class and category $(\mathrm{H})$} \\
\hline & $\begin{array}{l}\text { Long-term } \\
(8 \mathrm{~h}) / \mathrm{ppm}\end{array}$ & $\begin{array}{l}\text { Short-term } \\
(15 \mathrm{~min}) / \mathrm{ppm}\end{array}$ & & $\begin{array}{l}300 \\
301 \\
302 \\
304\end{array}$ & 311 & $\begin{array}{l}314 \\
315\end{array}$ & 317 & 319 & $\begin{array}{l}330 \\
331 \\
332\end{array}$ & $\begin{array}{l}335 \\
336 \\
372 \\
373\end{array}$ & $\begin{array}{l}340 \\
341\end{array}$ & 350 & $\begin{array}{l}400 \\
410 \\
411 \\
412\end{array}$ \\
\hline Formaldehyde & 2 & 2 & & $\checkmark$ & $\checkmark$ & $\checkmark$ & $\checkmark$ & & $\checkmark$ & & $\checkmark$ & $\checkmark$ & \\
\hline Acetaldehyde & 20 & 50 & $\checkmark$ & & & & & $\checkmark$ & & $\checkmark$ & $\checkmark$ & $\checkmark$ & \\
\hline Acetone & 500 & 1500 & $\checkmark$ & & & & & $\checkmark$ & & $\checkmark$ & & & \\
\hline Acrolein & 0.02 & 0.05 & $\checkmark$ & $\checkmark$ & $\checkmark$ & $\checkmark$ & & & $\checkmark$ & & & & $\checkmark$ \\
\hline Methyl ethyl ketone & 200 & 300 & $\checkmark$ & & & & & $\checkmark$ & & $\checkmark$ & & & \\
\hline Methyl propyl ketone & 200 & 250 & $\checkmark$ & $\checkmark$ & & & & $\checkmark$ & & $\checkmark$ & & & \\
\hline Heptan-2-one & 50 & 100 & $\checkmark$ & $\checkmark$ & & & & & $\checkmark$ & & & & \\
\hline Heptan-3-one & 35 & 100 & $\checkmark$ & & & & & $\checkmark$ & $\checkmark$ & & & & \\
\hline propionic acid & 10 & 15 & & & & $\checkmark$ & & & & & & & \\
\hline n-Pentane & 600 & - & $\checkmark$ & $\checkmark$ & & & & & & $\checkmark$ & & & $\checkmark$ \\
\hline dibutyl hydroxytoluene & - & - & & & & & & & & & & & $\checkmark$ \\
\hline Acetic acid & - & - & $\checkmark$ & & & $\checkmark$ & & & & & & & \\
\hline Butanoic acid & - & - & & & & $\checkmark$ & & & & & & & \\
\hline Pentanoic acid & - & - & & & & $\checkmark$ & & & & & & & $\checkmark$ \\
\hline Propanone & - & - & $\checkmark$ & & & & & $\checkmark$ & & $\checkmark$ & & & \\
\hline 1,2-Dichloroethane & 5 & - & $\checkmark$ & $\checkmark$ & & $\checkmark$ & & $\checkmark$ & & $\checkmark$ & & $\checkmark$ & \\
\hline Styrene & 100 & 250 & $\checkmark$ & & & $\checkmark$ & & $\checkmark$ & $\checkmark$ & $\checkmark$ & & & \\
\hline Ethylbenzene & 100 & 125 & $\checkmark$ & $\checkmark$ & & & & & $\checkmark$ & $\checkmark$ & & & \\
\hline Benzene & 1 & - & $\checkmark$ & $\checkmark$ & & $\checkmark$ & & $\checkmark$ & & $\checkmark$ & $\checkmark$ & $\checkmark$ & \\
\hline
\end{tabular}

H224/H225/H226 flammable liquid and vapours, H300/H301/H302/H304 oral toxicity, H311 dermal toxicity, $H 314 / H 315$ skin irritation/corrosion, $H 317$ skin sensitization, $H 319$ eye damage/eye irritation, $H 330 / 331 / 332$ inhalation toxicity, $H 335 / H 336 / H 372 / H 373$ specific target organ toxicity, $H 340 / H 341$ germ cell mutagenicity, $H 350$ carcinogen, $H 400 / H 410 / H 411 / H 412$ hazardous to the aquatic environment 
LDPE. Water sachets made of LDPE and HDPE bottle caps were used in these experiments.

Commercially available silica sand with a particle density of $2.65 \mathrm{~g} \mathrm{~cm}^{-3}$ was used as the filler. This was dried and sieved into three different size fractions with particle sizes (d) in $\mathrm{mm}$ of $\mathrm{d}<0.30,0.30<\mathrm{d}<0.60$ and $0.60<\mathrm{d}<1.35$. The three sizes were assumed to have average particles sizes of $0.15 \mathrm{~mm}, 0.45 \mathrm{~mm}$, and $0.98 \mathrm{~mm}$.

Test samples were produced using two processes. The oven moulding technique (OMT) involved heating layers of a mix of plastics and sand to the required processing temperature (Wild Barefield M253 oven with a temperature sensitivity of $\pm 5^{\circ} \mathrm{C}$ ). The mix was stirred after 7,10 and $15 \mathrm{~min}$ at the temperature required to achieve a homogeneous mix. The mix was then cast into $50 \mathrm{~mm}$-cubed steel moulds, pre-heated to at least $150{ }^{\circ} \mathrm{C}$ to ensure slow cooling, effective compaction and prevent deformation due to rapid temperature change $[35,36]$. The mix was then compacted and cooled to room temperature to form the plastic bonded sand samples. The test samples were processed at a temperature range between 250 and $375{ }^{\circ} \mathrm{C}$ at $25^{\circ} \mathrm{C}$ intervals.

In the heat-mixing technique (HMT) the plastic was melted in a covered saucepan on a hotplate. The required quantity of sand was then mixed into the molten thermoplastic. Mixing was continued until a homogenous mix was formed which was then compacted into pre-heated $50 \mathrm{~mm}$ cubed steel moulds. The samples were formed after cooling to room temperature $[35,36]$.

Table 2 shows the different mix designs of samples prepared and tested in this work. The effect of processing temperature on the compressive and flexural strength of plastic bonded sand has been investigated using the OMT preparation method. The effect of thermoplastic binder type on the compressive strength was also investigated, although the different plastics required different melt times to produce optimum samples. LDPE samples were heated for $70 \mathrm{~min}$ while HDPE samples were heated for $90 \mathrm{~min}$. The effect of sand proportions and sand particle size on the plastic bonded sand properties using the HMT production method has also been investigated.

A Zwick Roell 1474 test machine was used to determine compressive strengths, plasticity, and elastic modulus. Compressive loads were applied at a strain rate of $10 \mathrm{~mm} \mathrm{~min}^{-1}$ until the samples exhibited $10 \%$ deformation or the applied stress had reduced after peak load to $10 \%$ of the peak strength. Vernier callipers were used to measure sample dimensions for stress-strain computations and data outputs were analysed using the TestXpert 3 version 1.11 software to produce compressive stress-strain curves.

Three-point bending tests were conducted in accordance with ASTM C580-02 (Zwick Roell Z010). At least five samples were tested, and the results averaged to give each data point. Tests were completed at a crosshead speed of $1 \mathrm{~mm} \mathrm{~min} \mathrm{~m}^{-1}$ using a support distance (L) of $30 \mathrm{~mm}$. The sample bar depth (d) and width (b) were measured using Vernier callipers. TestXpert 3 software measured deflections (D) at the centre of the beam to generate force-displacement curves. The total work of fracture was computed from the area under the stress-strain curves. Flexural stress and strain were calculated using the following equations:

Table 2 Systemic variation in mix design of test samples to investigate the effect of processing temperature, sand particle sizes, thermoplastics binder type and proportions on mechanical properties of plastic bonded sand

\begin{tabular}{|c|c|c|c|c|c|c|}
\hline \multirow[t]{2}{*}{ Experiment } & \multirow[t]{2}{*}{ Plastic type } & \multirow{2}{*}{$\begin{array}{l}\text { Sand to plas- } \\
\text { tic propor- } \\
\text { tions } \\
\text { (wt. } \% \text { ) }\end{array}$} & \multirow{2}{*}{$\begin{array}{l}\text { Sand particle size } \\
\text { (d in } \mathrm{mm})\end{array}$} & \multicolumn{2}{|l|}{ Processing parameters } & \multirow{2}{*}{$\begin{array}{l}\text { Number } \\
\text { of sam- } \\
\text { ples }\end{array}$} \\
\hline & & & & $\begin{array}{l}\text { Temp } \\
\left({ }^{\circ} \mathrm{C}\right)\end{array}$ & $\begin{array}{l}\text { Time } \\
(\min )\end{array}$ & \\
\hline $\begin{array}{l}\text { Effect of processing temperatures on com- } \\
\text { pressive strength (OMT) }\end{array}$ & LDPE & 75.0 & $\mathrm{~d}<0.30$ & $250-375$ (at $25^{\circ} \mathrm{C}$ intervals) & 32 & 18 \\
\hline $\begin{array}{l}\text { Effect of processing temperatures on flex- } \\
\text { ural strength (OMT) }\end{array}$ & LDPE & 75.0 & $\mathrm{~d}<0.30$ & $250-375$ (at $25^{\circ} \mathrm{C}$ intervals) & 17 and 27 & 60 \\
\hline \multirow{2}{*}{$\begin{array}{l}\text { Effect of thermoplastic binder type on } \\
\text { compressive strength (HMT) }\end{array}$} & LDPE & $50-83.3$ & $\mathrm{~d}<0.30$ & $200-300$ & 70 & 15 \\
\hline & HDPE & $50-83.3$ & $\mathrm{~d}<0.30$ & $250-300$ & 90 & 15 \\
\hline \multirow{6}{*}{$\begin{array}{l}\text { Effect of sand proportions and particle size } \\
\text { on plastic bonded sand properties (HMT) }\end{array}$} & \multirow[t]{3}{*}{ LDPE } & $50-83.3$ & $\mathrm{~d}<0.30$ & $200-300$ & 70 & 15 \\
\hline & & $50-83.3$ & $0.30<\mathrm{d}<0.60$ & $200-300$ & 70 & 15 \\
\hline & & $50-83.3$ & $0.60<\mathrm{d}<1.35$ & $200-300$ & 70 & 15 \\
\hline & \multirow[t]{3}{*}{ HDPE } & $50-83.3$ & $\mathrm{~d}<0.30$ & $250-300$ & 90 & 15 \\
\hline & & $50-83.3$ & $0.30<\mathrm{d}<0.60$ & $200-300$ & 90 & 15 \\
\hline & & $50-83.3$ & $0.60<d<1.35$ & $200-300$ & 90 & 15 \\
\hline
\end{tabular}

$O M T$ oven moulding technique, $H M T$ heat mixing technique 
Flexural stress $\left(\sigma_{\mathrm{f}}\right)=\frac{3 \mathrm{FL}}{2 \mathrm{bd}^{2}} ; \quad$ Flexural $\operatorname{strain}\left(\varepsilon_{\mathrm{f}}\right)=\frac{6 \mathrm{Dd}}{\mathrm{L}^{2}}$

Thermal conductivities of plastic bonded sand samples were measured using a non-destructive test based on the transient plane source technique in accordance with ISO 22007-2:2015 (Hot Disk M1 analyser, Thermal 18 Instruments Ltd). The hot disk sensor was placed between the surfaces of two block samples at room temperature $\left(23.3{ }^{\circ} \mathrm{C}\right)$. Heat was applied from the sensor at an output power of $0.25 \mathrm{~mW}$ for $40 \mathrm{~s}$ and temperature was measured as a function of time [37].

Images of fractured surfaces of samples tested in threepoint bending were obtained using scanning electron microscopy (SEM, Hitachi TM4000Plus machine).

Thermogravimetric Analysis (TGA) was used to study the effects of temperature and time on plastic degradation (Mettler Toledo TGA 2 with a $70 \mu \mathrm{l}$ alumina crucible). $6 \mathrm{mg}$ of LDPE was heated from $30^{\circ} \mathrm{C}$ to $600^{\circ} \mathrm{C}$ at a constant rate of $10 \mathrm{~K} \mathrm{~min}^{-1}$ in air and $\mathrm{N}_{2}$ under a purge gas flow rate of $50 \mathrm{ml} \mathrm{min}^{-1}$. Test samples were also heated at $260{ }^{\circ} \mathrm{C}$ and $310^{\circ} \mathrm{C}$ for $20 \mathrm{~min}$ in isothermal experiments to observe the effects of processing time on thermal degradation in air.

\section{Results}

The effect of processing temperature on the stress-strain behaviour and compressive strength of LDPE plastic bonded sand samples containing $75 \mathrm{wt} . \%$ sand with a particle size $\mathrm{d} \leq 300 \mu \mathrm{m}$ is shown in Fig. 3. Increasing the temperature from 185 to $240{ }^{\circ} \mathrm{C}$ increases the compressive strength by $30-65 \%$ depending on the sand content. Processing at temperatures between 250 and $350{ }^{\circ} \mathrm{C}$ produced no significant variation in compressive strength. Higher temperatures decreased compressive strengths and reduced the work of fracture due to plastic degradation. Samples prepared at $375{ }^{\circ} \mathrm{C}$ could support approximately $20 \%$ of the maximum load at a strain of 0.075 while samples prepared at $250{ }^{\circ} \mathrm{C}$ retained at least $74 \%$ of ultimate strength at a strain of 0.024 . The compressive modulus of plastic bonded sand determined between 0 and 0.012 strain varied between 0.6 and $0.8 \mathrm{GPa}$.

The failure modes of the samples tested in compression are shown in Fig. 4. Samples processed above $325^{\circ} \mathrm{C}$ failed along a $45^{\circ}$ shear plane and disintegrated into smaller pieces [35]. Below $325^{\circ} \mathrm{C}$ samples failed along the compaction layers without disintegrating due to the heterogeneity of the samples processed at lower temperatures.

The effects of processing temperatures on the flexural properties of plastic bonded sand samples are shown in Fig. 5. The flexural modulus of samples processed above $275{ }^{\circ} \mathrm{C}$ ranged between 0.5 to $0.7 \mathrm{GPa}$. Flexural strengths of samples processed for $27 \mathrm{~min}$ remained constant between

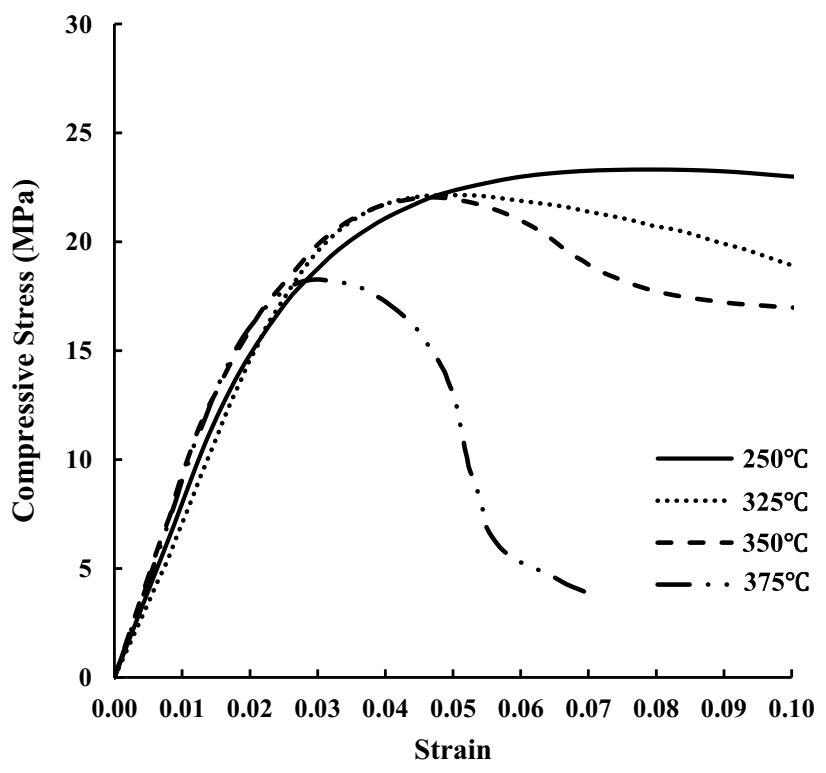

(a)

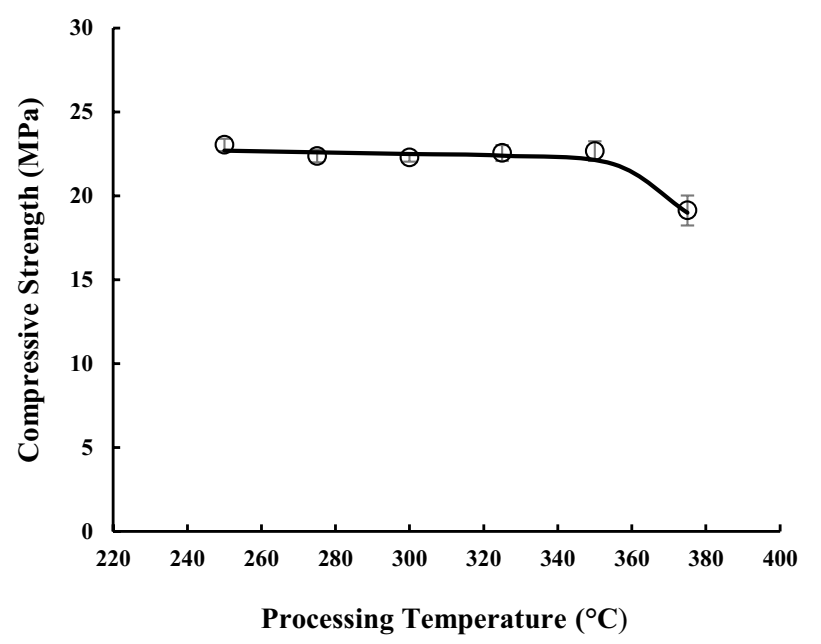

(b)

Fig. 3 The effect of varying processing temperatures on: a stressstrain behaviour of LDPE plastic bonded sand with $75 \mathrm{wt} \%$ sand and $\mathrm{d} \leq 300 \mu \mathrm{m}$. Increasing brittleness is observed with increasing temperature. $\mathbf{b}$ the compressive strength of LDPE bonded sand with $75 \mathrm{wt} . \%$ sand and $\mathrm{d} \leq 300 \mu \mathrm{m}$

250 and $325{ }^{\circ} \mathrm{C}$. Processing above $325{ }^{\circ} \mathrm{C}$ caused a significant reduction in flexural strength and a reduced work of fracture. Increasing processing time produces a more homogenous sample with improved sand packing that enhances the compressive and flexural strengths. However, Fig. $5 b$ shows that LDPE plastic bonded sand samples processed for $17 \mathrm{~min}$ had a greater flexural strength than samples processed for $27 \mathrm{~min}$.

The work of fracture of plastic bonded sand samples decreased with increasing processing temperature as shown 


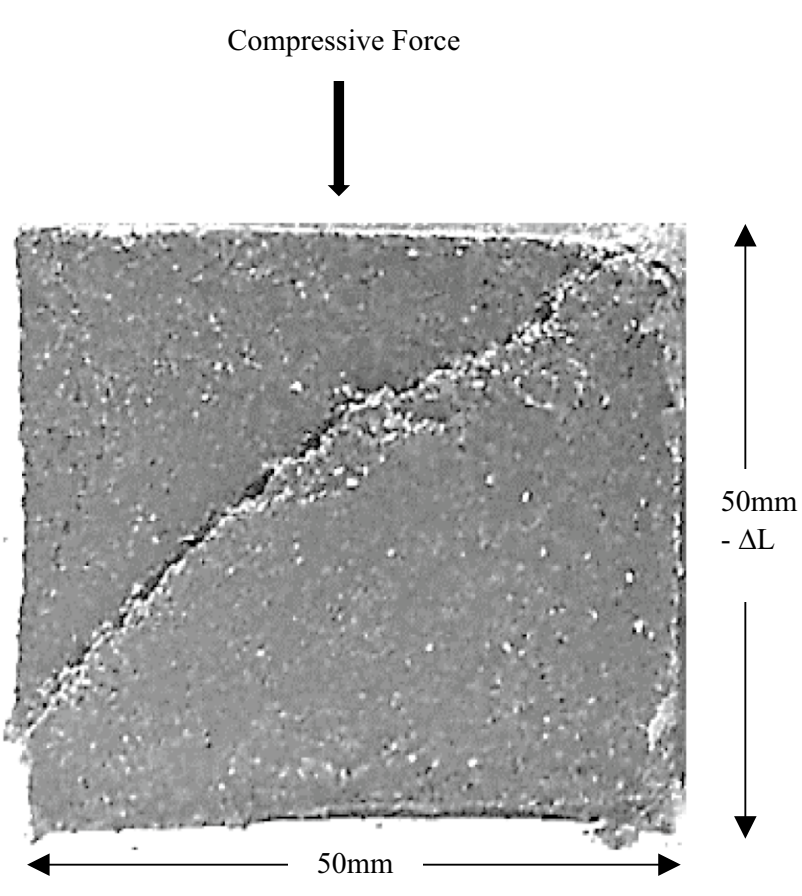

(a)

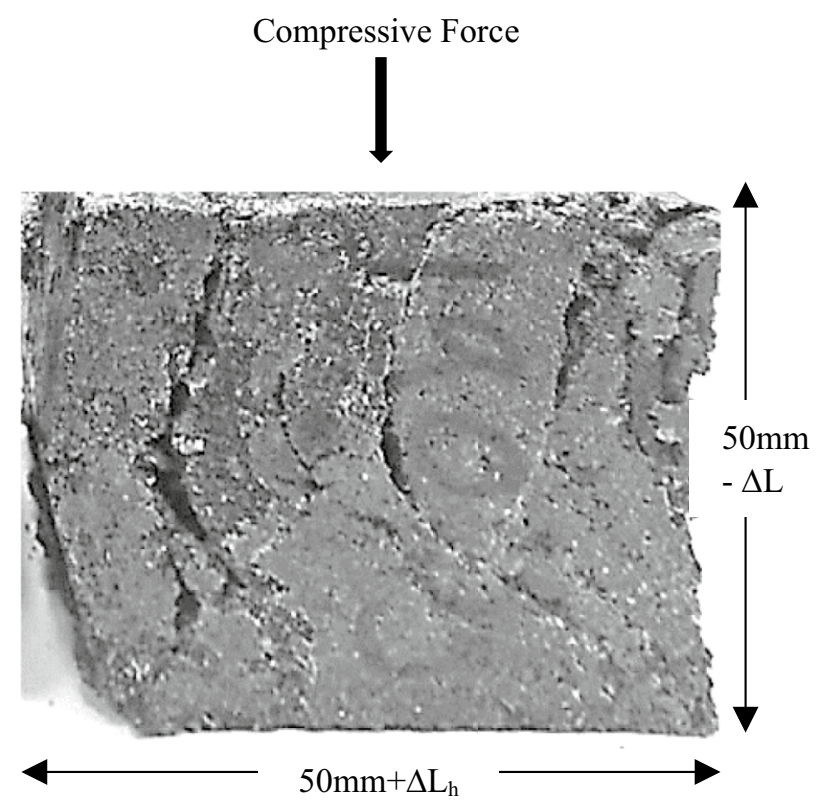

(b)

Fig. 4 Failure modes observed in LDPE plastic bonded sand samples with $75 \mathrm{wt} . \%$ sand and $\mathrm{d} \leq 300 \mu \mathrm{m}$ : a approximate $45^{\circ}$ shear plane observed for samples processed at $>325{ }^{\circ} \mathrm{C}$. b shear failure along compaction layers in samples processed at $\leq 325{ }^{\circ} \mathrm{C}$. $\Delta \mathrm{L}$ refers to the deformation in direction of the applied compressive force and $\Delta \mathrm{L}_{\mathrm{h}}$ is the deformation perpendicular to the applied compressive force

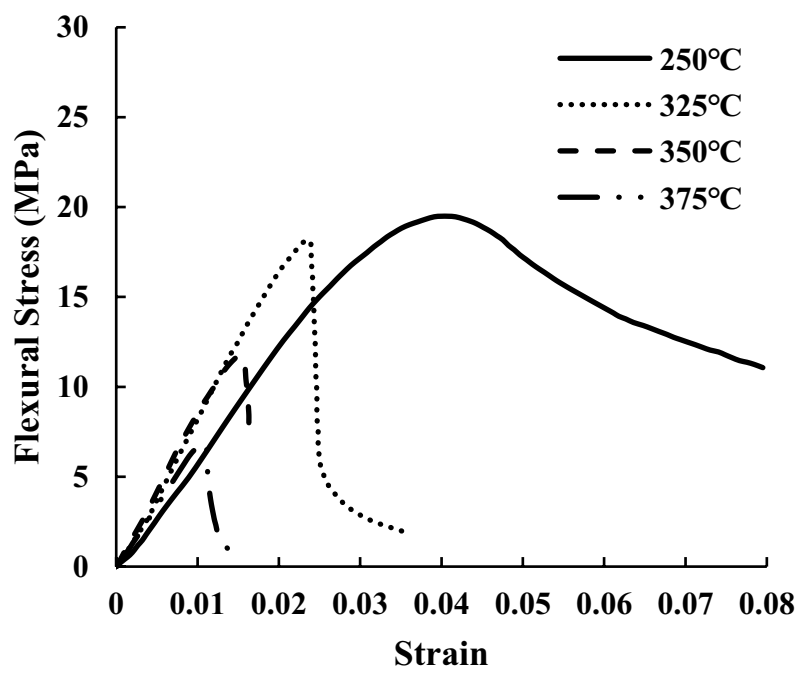

(a)

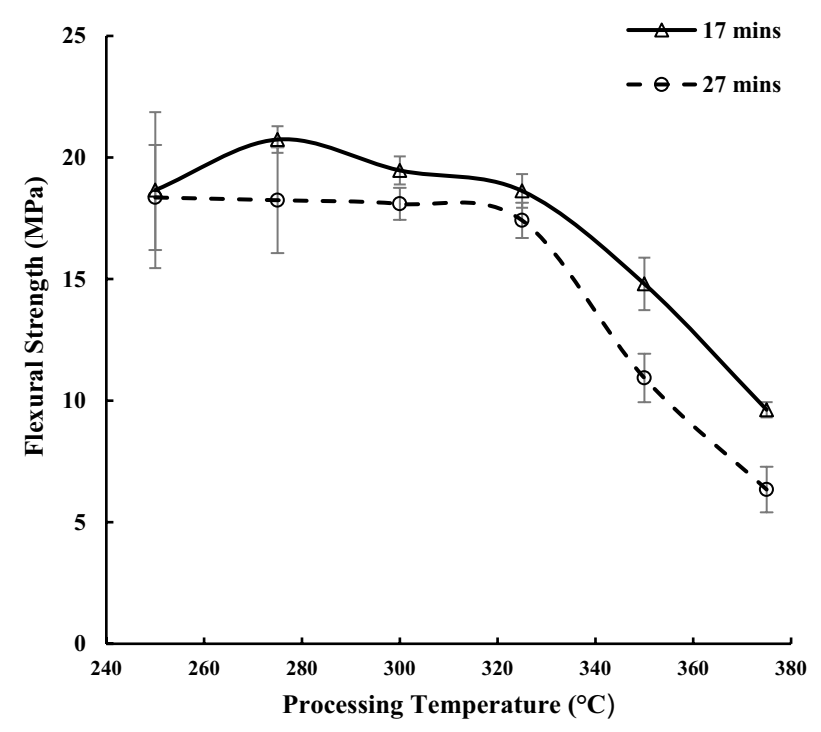

(b)

Fig. 5 The effect of varying processing temperatures on: a Flexural stress-strain behaviour of LDPE plastic bonded sand with $75 \mathrm{wt} . \%$ sand and $d \leq 300 \mu \mathrm{m}$. Increasing brittleness is observed with increasing temperature. b Flexural strength of LDPE bonded sand with $75 \mathrm{wt} . \%$ sand and $\mathrm{d} \leq 300 \mu \mathrm{m}$, processed for 17 and $27 \mathrm{~min}$

in Fig. 6. Work of fracture data for samples processed at $250{ }^{\circ} \mathrm{C}$ for $17 \mathrm{~min}$ was inconsistent due to sample heterogeneity. The work of fracture reduced rapidly at $275^{\circ} \mathrm{C}$. Increasing processing temperature from 325 to $375{ }^{\circ} \mathrm{C}$ reduced the average work of fracture of LDPE samples processed for $17 \mathrm{~min}$ from 68 to $10 \%$ of the value at $275^{\circ} \mathrm{C}$. For samples processed for $27 \mathrm{~min}$, the work of fracture reduced from 64 to $13 \%$ of the value at $275^{\circ} \mathrm{C}$. This was due to the thermal degradation of the thermoplastic binder resulting from longer heat exposure at elevated temperatures. 


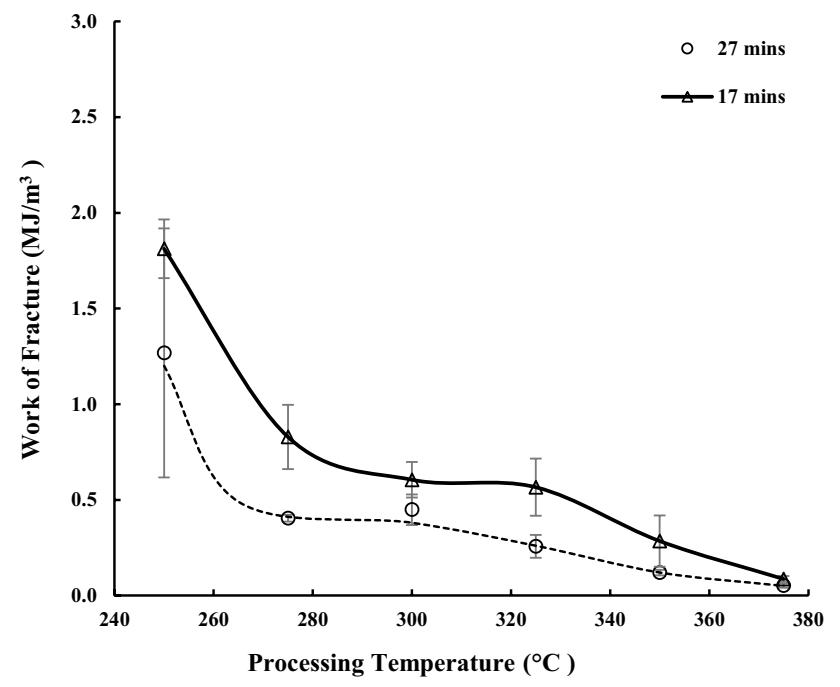

Fig. 6 The effect of processing temperatures on the work of fracture of LDPE plastic bonded sand processed for 17 and $27 \mathrm{~min}$. Error bars are indicative of the standard deviation of 5 samples

Figure 7 shows the effect of sand proportions and sand particle sizes on the compressive strength of LDPE and HDPE plastic bonded sand samples. The optimum sand proportions that gave the highest compressive strengths ranged between 65 to 75 wt. $\%$ for LDPE and 65 to $80 \mathrm{wt} \%$ for HDPE, depending on sand particle size (d). For the LDPE samples, sand with $\mathrm{d}<300 \mu \mathrm{m}$, $300 \mu \mathrm{m}<\mathrm{d}<600 \mu \mathrm{m}$, and $600 \mu \mathrm{m}<\mathrm{d}<1.35 \mathrm{~mm}$ produced maximum compressive strengths of $27.2 \mathrm{MPa}, 21.8 \mathrm{MPa}$, and 20.1 MPa, respectively. Optimum sand proportions for compressive strength decreased with decreasing sand particle sizes. Increasing sand content above the optimum proportions caused a more rapid decline in the compressive strength for LDPE samples with the same sand particle size. HDPE plastic bonded sand samples had maximum compressive strengths between 31.4 and $37.1 \mathrm{MPa}$ depending on the sand particle size. The maximum compressive strengths decreased with increasing sand particle size. However, the relationship between compressive strength and sand particle size was dependent on sand proportions. The compressive strength of LDPE samples with $\leq 75 \mathrm{wt} . \%$ sand decreased with increasing sand particle sizes. Increasing sand particle sizes increased the compressive strength of LDPE samples with $>75$ wt.\% sand and $\mathrm{d}<500 \mu \mathrm{m}$. Further increase in sand particle sizes above $500 \mu \mathrm{m}$ decreased LDPE compressive strength. In contrast, for HDPE samples, the compressive strength decreased with increasing sand particle sizes irrespective of sand proportions. Optimised plastic bonded sand compares favourably with C20/25 concrete with a compressive modulus of $31 \mathrm{GPa}$ after 28 curing days. However, it has only $2-2.5 \%$ of the stiffness of concrete.

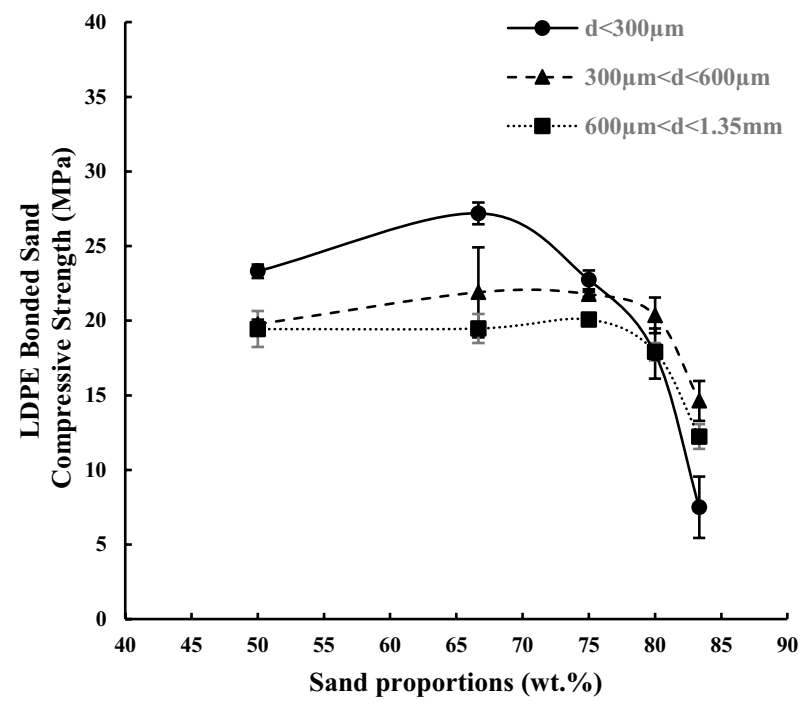

(a)

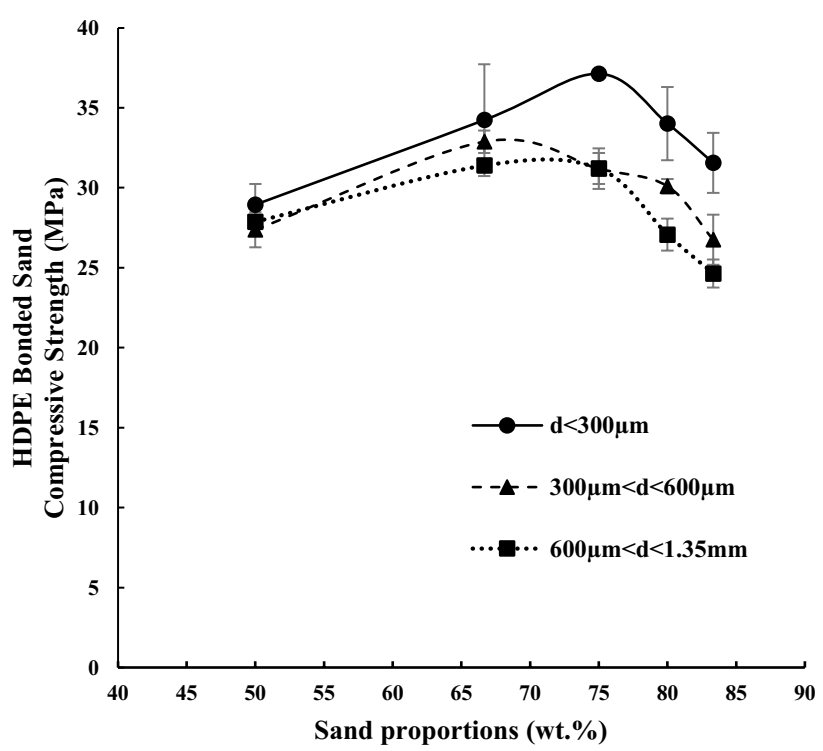

(b)

Fig. 7 The effect of varying sand proportions and particle sizes on the compressive strengths of: a LDPE plastic bonded sand and b HDPE plastic bonded sand. Error bars indicate the standard deviation of the compressive strength values for three test samples

The effects of varying sand addition on the stress-strain behaviour of samples are shown in Fig. 8. LDPE samples are more ductile with lower compressive strengths and toughness than HDPE samples. The work of fracture of samples ranged between 0.6 to $2.3 \mathrm{MJ} \mathrm{m}^{-3}$ for LDPE samples and 1.0 to $2.1 \mathrm{MJ} \mathrm{m}^{-3}$ for HDPE samples depending on sand addition and particle size. The work of fracture of LDPE samples increased with increasing sand proportions to 68 wt.\%. The sand particle size had no impact on the work of 


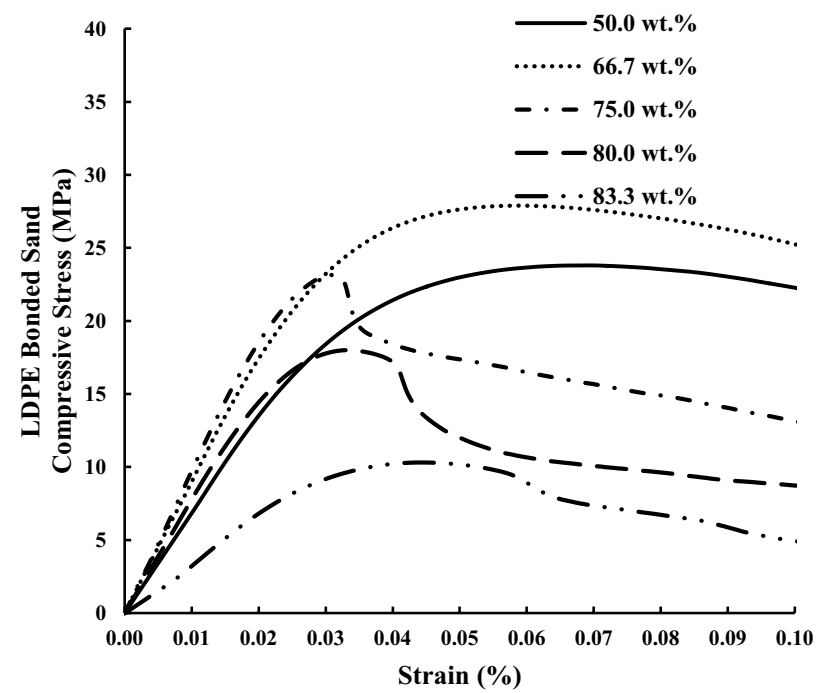

(a)

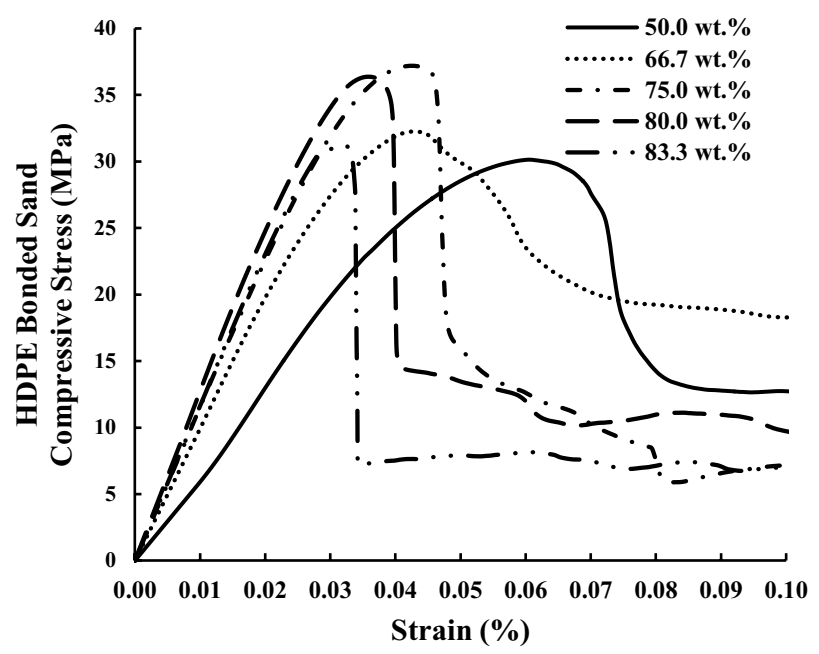

(b)

Fig. 8 The effects of varying sand proportions on the stress-strain behaviour of: a LDPE bonded Sand with $\mathrm{d}<300 \mu \mathrm{m}$. b HDPE bonded sand with $\mathrm{d}<300 \mu \mathrm{m}$

fracture of LDPE samples with $\geq 75 \mathrm{wt} . \%$ sand. The work of fracture of LDPE samples with $\leq 75 \mathrm{wt} \%$ sand increased with decreasing sand particle size. A maximum work of fracture of $2.1 \mathrm{MJ} \mathrm{m}^{-3}, 1.9 \mathrm{MJ} \mathrm{m}^{-3}$ and $2.0 \mathrm{MJ} \mathrm{m}^{-3}$ was observed for HDPE samples with $\mathrm{d}<300 \mu \mathrm{m}, 300 \mu \mathrm{m}<\mathrm{d}<600 \mu \mathrm{m}$, and $600 \mu \mathrm{m}<\mathrm{d}<1.35 \mathrm{~mm}$, respectively. The work of fracture required to fracture HDPE samples increased up to the optimum sand addition of $67 \mathrm{wt} . \%$. Further increases in sand content decreased HDPE sample work of fracture irrespective of sand particle size.

The elastic modulus of LDPE samples was between 0.5 and 1.0 MPa and HDPE samples had an elastic modulus between 1.2 and 1.3 MPa. A 75 wt.\% sand addition produced

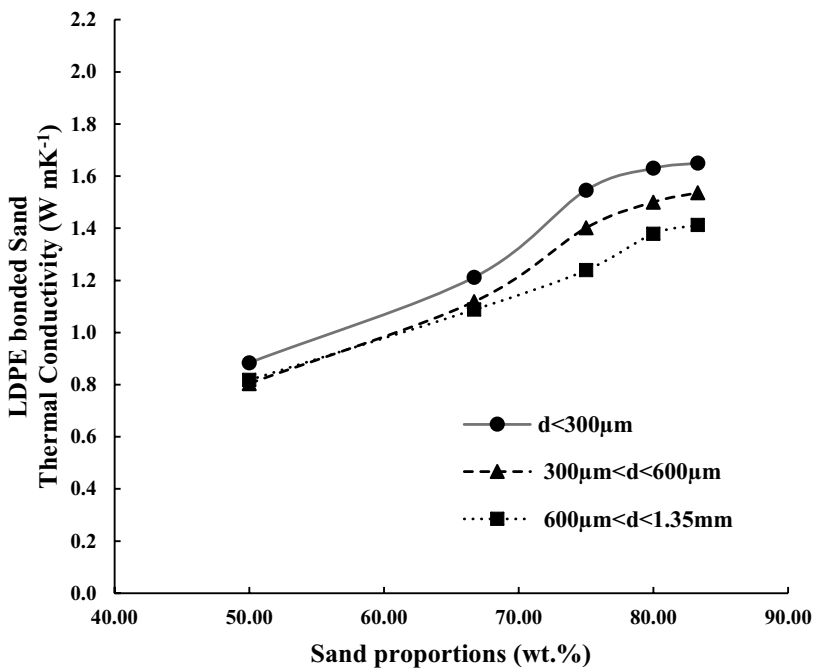

(a)

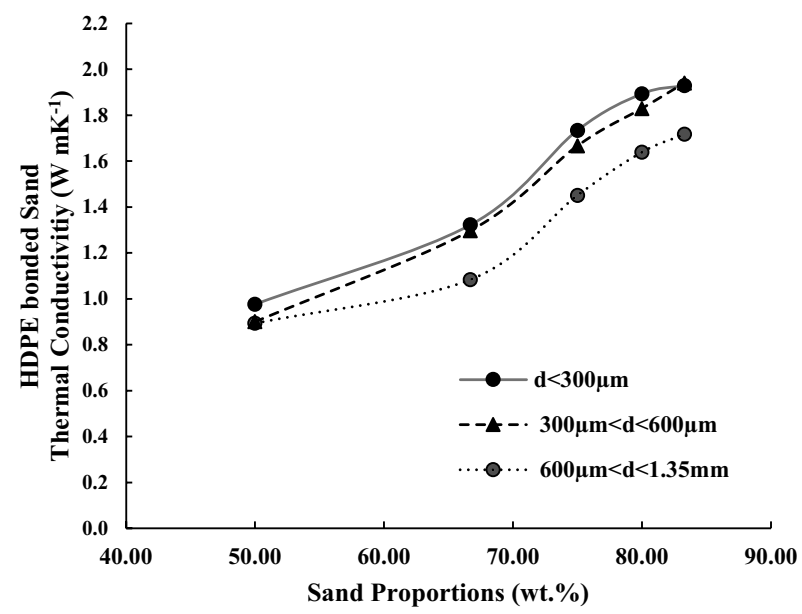

(b)

Fig. 9 The effect of varying sand proportions and particle sizes on the thermal conductivities of: a LDPE bonded sand and $\mathbf{b}$ HDPE bonded sand

the highest elastic modulus in LDPE samples. The elastic modulus of LDPE samples with $\leq 75 \mathrm{wt} . \%$ sand decreased with increasing sand particle size. For LDPE samples with more than $75 \mathrm{wt} . \%$ sand the elastic modulus increased with increasing sand particles size and $80 \mathrm{wt} . \%$ sand additions produced the highest elastic modulus in HDPE samples.

The thermal conductivities of LDPE and HDPE samples were between 0.8 to $1.6 \mathrm{~W} \mathrm{mK}^{-1}$ and 1.0 to $1.9 \mathrm{~W} \mathrm{mK}^{-1}$ respectively. Figure 9 shows that thermal conductivity of plastic bonded sand increases with increasing sand content and decreases with increasing sand particle sizes.

Thermal degradation of the plastic binder changes the fracture properties of plastic bonded sand. SEM images in Fig. 10 shows the higher ductility in samples processed at $275^{\circ} \mathrm{C}$ with long stretched-out plastic strands producing a 

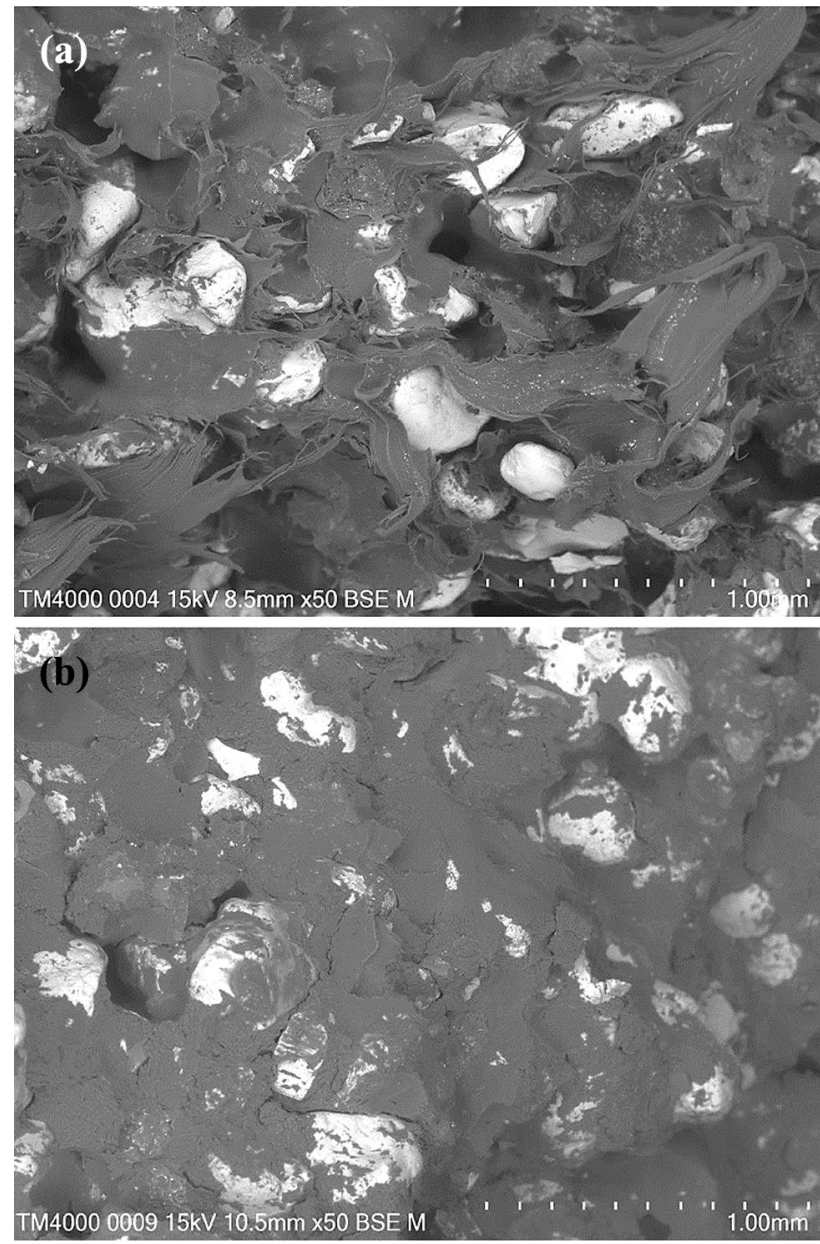

Fig. 10 SEM images of fractured LDPE bonded sand samples showing: a rough surfaces with long plastic strands in samples processed at $275^{\circ} \mathrm{C}$ and $\mathbf{b}$ smooth surfaces of samples processed at $\geq 325^{\circ} \mathrm{C}$ rough fracture surface. Increasing the processing temperature to above $325{ }^{\circ} \mathrm{C}$ resulted in a much smoother fracture surface with minute cracks within the plastic-sand matrix. These defects act as stress concentration points which caused brittle failure in samples processed at higher temperatures.

Figure 11 shows the TGA curves of LDPE waste plastics. Thermal degradation begins at $400{ }^{\circ} \mathrm{C}$ and $240{ }^{\circ} \mathrm{C}$ in $\mathrm{N}_{2}$ and air respectively. The degradation rate rapidly increased with increasing temperatures $>450{ }^{\circ} \mathrm{C}$ in $\mathrm{N}_{2}$. Peak degradation occurred at $490{ }^{\circ} \mathrm{C}$ and $99.5 \%$ of LDPE mass was lost by $507{ }^{\circ} \mathrm{C}$. Thermal degradation in air occurred in three distinct phases: low-rate thermal oxidation below $0.25 \%$ ${ }^{\circ} \mathrm{C}^{-1}$, rapid degradation above $0.25 \%{ }^{\circ} \mathrm{C}^{-1}$, and degradation of residuals. The degradation rate increased gradually with increasing temperature until $370{ }^{\circ} \mathrm{C}$. Higher temperatures sharply increased the degradation rate to a peak at $450{ }^{\circ} \mathrm{C}$. Degradation rate then slowed until $99.5 \%$ of the LDPE mass was lost at $570{ }^{\circ} \mathrm{C}$. The isothermal experiments revealed that peak degradation of samples occurred at the onset of the isothermal temperatures $\left(310^{\circ} \mathrm{C}\right.$ and $\left.260{ }^{\circ} \mathrm{C}\right)$ and then declined due the accumulation of degraded products on the sample surface. Peak degradation at $310^{\circ} \mathrm{C}$ was $62 \%$ greater than at $260{ }^{\circ} \mathrm{C}$. After 6 min exposure to the isothermal temperatures, both samples lost $50 \%$ of the total mass lost over the 20 min isothermal period.

\section{Discussion}

Transforming waste LDPE and HDPE plastics into plastic bonded sand composites is a low-cost recycling option. Plastic bonded sand composites are durable lightweight materials produced with low energy requirements. LDPE and HDPE plastic bonded sand have properties suitable for use in selected construction products as shown in Table 3.

Understanding the effects of the processing temperature, sand content and sand particle sizes can optimise plastic
Fig. 11 TGA curves of LDPE waste plastic showing the mass loss and rate of mass loss with increasing temperature at a heating rate of $10 \mathrm{~K} \mathrm{~min}^{-1}$ in air and nitrogen

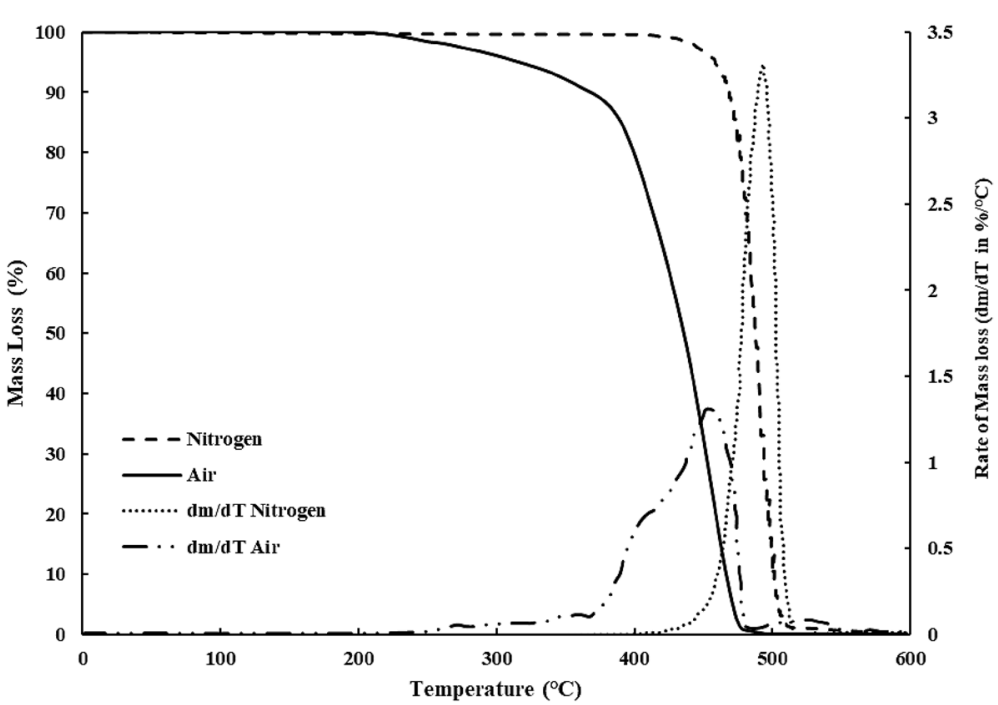


Table 3 The suitability of LDPE bonded sand and HDPE bonded sand for selected applications

\begin{tabular}{|c|c|c|c|c|c|}
\hline Designatior & & $\begin{array}{l}\text { Minimum aver- } \\
\text { age compressive } \\
\text { strength }(\mathrm{MPa})\end{array}$ & $\begin{array}{l}\text { Maximum } \\
\text { water absorp- } \\
\text { tion }(\%)\end{array}$ & LBS & HBS \\
\hline \multirow[t]{10}{*}{ Building } & \multicolumn{5}{|c|}{ Building brick (ASTM-C62) } \\
\hline & SW & 20.7 & 13.26 & $\sqrt{ }$ & $\sqrt{ }$ \\
\hline & MW & 17.2 & 19.36 & $\sqrt{ }$ & $\sqrt{ }$ \\
\hline & NW & 10.3 & No limit & $\sqrt{ }$ & $\sqrt{ }$ \\
\hline & \multicolumn{5}{|c|}{ Facing brick (ASTM-C216) } \\
\hline & SW & 20.7 & 13.26 & $\sqrt{ }$ & $\sqrt{ }$ \\
\hline & MW & 17.2 & 19.36 & $\sqrt{ }$ & $\sqrt{ }$ \\
\hline & \multicolumn{5}{|c|}{ Thin veneer brick (ASTM-C1088) } \\
\hline & Ext & 17.2 & 13.26 & $\sqrt{ }$ & $\sqrt{ }$ \\
\hline & Int & 17.2 & 19.36 & $\sqrt{ }$ & $\sqrt{ }$ \\
\hline \multirow[t]{9}{*}{ Pavement } & \multicolumn{5}{|c|}{ Pedestrian and light traffic paving brick (ASTM-C902) } \\
\hline & SX & 27.6 & 8 & $\mathrm{x}$ & $\sqrt{ }$ \\
\hline & MX & 20.7 & 14 & $\sqrt{ }$ & $\sqrt{ }$ \\
\hline & NX & 20.7 & No limit & $\sqrt{ }$ & $\sqrt{ }$ \\
\hline & \multicolumn{5}{|c|}{ Heavy vehicular paving brick (ASTM-C1272) } \\
\hline & $\mathrm{F}$ & 69.0 & 6 & $\mathrm{x}$ & $\mathrm{x}$ \\
\hline & $\mathrm{R}$ & 55.2 & 6 & $\mathrm{x}$ & $\mathrm{x}$ \\
\hline & \multicolumn{5}{|c|}{ Solid interlocking paving units (ASTM C936) } \\
\hline & & 50.0 & 7 & $\mathrm{x}$ & $\mathrm{x}$ \\
\hline
\end{tabular}

$L B S$ LDPE plastic bonded sand, HBS HDPE plastic bonded sand, $S W$ severe weathering conditions, $M W$ medium weathering conditions, $N W$ for use in negligible weathering conditions, Ext grade exterior: for use where high resistance to cyclic freezing and thawing damage is desired, Int grade interior: for use where moderate resistance to cyclic freezing and thawing damage is permissible, $S X$ for use where brick may be frozen with saturated water, $\mathrm{MX}$ - for exterior use where freezing resistance is not required, $N X$ for exterior use but may be accepted for interior use where freezing resistance is required. $F$ brick to be set in an aggregate setting bed, $R$ brick to be set in mortar or bituminous setting beds

bonded sand properties. The ideal processing temperature needs to achieve the ideal binder viscosities for effective incorporation of the sand into the plastic matrix to form the plastic bonded sand. The optimal processing temperature for plastic bonded sand produced using OMT and HMT ranged between 250 and $325^{\circ} \mathrm{C}$ and there was no significant variation in compressive and flexural strength of samples processed at such temperatures. These temperatures allow flow of the binder to reduce pores within the plastic-sand matrix. Increased cooling times also increase the degree of crystallinity $[38,39]$. Higher temperatures adversely affect plastic bonded sand properties due to thermal degradation of the plastic. Lower temperatures form heterogenous samples with compromised properties due to inefficient mixing.

Plastic bonded sand properties are influenced by the plastic matrix strength and the interfacial bonding between the plastic and sand. Sand encapsulation within the plastic binder through mechanical coupling and molecular bonding forms the bonding mechanism. For mechanical coupling, the sand surface irregularities are filled with the binder to form an interlocking pattern [40]. Higher sand content increase sand surface irregularities. Lower sand content reduces adhesion sites with increasing sand particle size. However, the low quantities of irregularly shaped sand particles slightly increase the effect of mechanical interlocking to overcome internal friction and de-wetting. Sand particles impose relatively higher strain rates to induce matrix strengthening in plastic bonded sand. The proportion and size of the sand particles influences the effects of these factors on the mechanical properties of Plastic bonded sand $[35,41]$.

Plastic bonded sand properties are controlled by the rigidity percolation theory [42]. The percolation point is a continuous path of interconnected filler particles formed as the filler content increases [43]. At the rigidity percolation point, there is just enough plastic binder to form a rigid interparticle network. Percolation of rigid regions is required to cause significant property changes. Rigidity percolation is achieved in plastic bonded sand with $20-25$ vol\% polymer content [43]. Above rigidity percolation, porosity increases because there is not enough binder volume to completely encapsulate sand particles. The use of larger sand particles in a given volume reduces the plastic bonding efficiency as the binder thickness encapsulating the sand reduces [35]. This is compensated for in normal Portland cement concrete using a higher water/ admixture ratio [44]. In plastic bonded sand, porosity increases and reduces the compressive strength [35]. The rigidity percolation point is controlled by the plastic binding capacities. Using different blends of thermoplastics alters the binder volume capacities. Coating sand with LDPE and PET reduced the compressive strength of the composites. Partial replacement of PET with PP reduced composite strengths due to the difficulty in blending the two thermoplastics because of varying melting points [36]. Further studies to investigate the optimum melting temperature for thermoplastic blends is recommended.

Optimised LDPE and HDPE plastic bonded sand samples are suitable for applications where strength, toughness or ductility are required including pavement, roof tiles and building partitions. Optimised plastic bonded sand has compressive strengths comparable to $\mathrm{C} 20 / 25$ concrete. The flexural to compressive strength ratio of LDPE plastic bonded sand is at least 5 times higher than concrete. PP bonded sand samples recorded a flexural strength approximately 3 times higher than concrete and 5 times higher than Asphalt concrete [45]. The optimum sand proportions that produced the maximum compressive strengths in LDPE and HDPE samples ranged between 65 to $75 \mathrm{wt} . \%$ and 65 to $80 \%$ wt. $\%$ respectively depending on sand particle size. This is consistent with values recorded for other plastic bonded sand materials including PET bonded laterite soil [36]. Plastics 
compounded with particulate fillers have reduced ductility as observed in polypropylene filled with paper disposable cups [46]. Plastic bonded sand exhibits a viscoelastic behaviour similar to the stress-strain properties of asphalt concrete [35]. Initial compressive loading yields a linear stress-strain curve. A shear plane is formed upon further loading due to the inter-particle frictional forces generated as the sand particles slide against each other. The curve flattens out at the peak friction coefficient point and descends linearly as the coefficient of friction reduces [47].

Plastic aggregates reduce the thermal conductivity of concrete due to the low thermal conductivity of plastics [48]. However, plastic bonded sand samples recorded a higher thermal conductivity than concrete or cement mortar. This was due to the increased heat transfer rate resulting from reduced sample porosity as observed in asphalt [49].

The existing heat-mixing process practiced in The Gambia provides a simple inexpensive plastic recycling option for job creation in low-income communities. However, an improved design is needed to address the health and safety concerns and improve the plastic bonded sand product quality. The primary mode of degradation during processing is due to thermal oxidation and not pyrolytic degradation since the typical processing temperatures are below the thermal degradation temperature in the anoxic environment $\left(400{ }^{\circ} \mathrm{C}\right)$. Further research to evaluate the risk of exposure to the off gases produced during plastic bonded sand processing is recommended. The safety concerns and significant heat losses make it difficult to upscale the technology for mass plastic bonded sand production. Extrusion and injection moulding techniques could effectively maintain lower processing temperatures to minimise off gases without compromising the product quality. Optimisation of processing parameters including melt-mixing temperature, moulding temperature and pressure for the extrusion and injection moulding techniques need to be prioritised for superior plastic bonded sand properties [39].

\section{Conclusions}

Waste LDPE and HDPE plastics can be used to manufacture plastic bonded sand materials using inexpensive processes with low energy and water requirements. This can provide an important reuse application for waste plastics and particularly in DCs. The processing parameters critical for optimising plastic bonded sand properties for selected construction materials are reported. Plastic bonded sand made with LDPE and HDPE are durable and suitable for use in pavement blocks, roof tiles and partition walls. Optimised samples have maximum compressive strengths that are comparable to $\mathrm{C} 20 / 25$ concrete and significantly higher than sandcrete. They are tough and have higher ductility and thermal conductivities than concrete. The structural arrangement of the thermoplastic binder and aggregate in the composite matrix affects properties. The processing temperature for achieving optimum plastic bonded sand properties was in the range between 250 and $325^{\circ} \mathrm{C}$. Higher temperatures reduce material toughness, plasticity, flexural and compressive strengths due to thermal degradation. Lower temperatures produced heterogenous samples with reduced strength due to inefficient mixing. Recycling waste plastics into plastic bonded sand is a resource efficient alternative with significant environmental and public health benefits compared to the existing disposal options in DCs. However, there is a risk of exposure to harmful off gases when plastic bonded sand is produced at temperatures $>250{ }^{\circ} \mathrm{C}$ in air. Processing temperature and time need to be controlled. Processing temperatures at $\leq 250{ }^{\circ} \mathrm{C}$ under anoxic conditions are recommended to control the off gases due to polymer degradation.

Acknowledgements The authors would like to thank Marcus Yio $(\mathrm{PhD})$ for the assistance in conducting some mechanical tests. Zoomlion Ghana Limited is also acknowledged for sponsoring this project. Thanks to Pierre Kamsouloum, Africa Environmental Sanitation (AFES) Consult and Waste AID UK for their support in the field work.

Funding This research work was funded by Zoomlion Ghana Limited through a $\mathrm{PhD}$ research at Imperial College London.

Data Availability Not applicable.

Code Availability Not applicable.

\section{Declarations}

Conflict of interest The authors declare that they have no competing interests.

Open Access This article is licensed under a Creative Commons Attribution 4.0 International License, which permits use, sharing, adaptation, distribution and reproduction in any medium or format, as long as you give appropriate credit to the original author(s) and the source, provide a link to the Creative Commons licence, and indicate if changes were made. The images or other third party material in this article are included in the article's Creative Commons licence, unless indicated otherwise in a credit line to the material. If material is not included in the article's Creative Commons licence and your intended use is not permitted by statutory regulation or exceeds the permitted use, you will need to obtain permission directly from the copyright holder. To view a copy of this licence, visit http://creativecommons.org/licenses/by/4.0/.

\section{References}

1. The Economist: The environment; The known unknowns of plastic pollution. Economist (United Kingdom) (2018). https://www. economist.com/international/2018/03/03/the-known-unknownsof-plastic-pollution. Accessed 28 Jan 2021. 
2. Gondal, M.A., Siddiqui, M.N.: Identification of different kinds of plastics using laser-induced breakdown spectroscopy for waste management. J. Environ. Sci. Heal. 42(13), 1989-1997 (2007)

3. Gall, S.C., Thompson, R.C.: The impact of debris on marine life. Mar. Pollut. Bull. 92(1-2), 170-179 (2015)

4. Derraik, J.G.B.: The pollution of the marine environment by plastic debris: a review. Mar. Pollut. Bull. 44(9), 842-852 (2002)

5. Saikia, N., De Brito, J.: Use of plastic waste as aggregate in cement mortar and concrete preparation: a review. Constr. Build. Mater. 34, 385-401 (2012)

6. Siddique, R., Khatib, J., Kaur, I.: Use of recycled plastic in concrete: a review. Waste Manag. 28(10), 1835-1852 (2008)

7. Huang, Y., Bird, R.N., Heidrich, O.: A review of the use of recycled solid waste materials in asphalt pavements. Resour. Conserv. Recycl. 52(1), 58-73 (2007)

8. Ahmadinia, E., Zargar, M., Karim, M.R., Abdelaziz, M., Ahmadinia, E.: Performance evaluation of utilization of waste polyethylene terephthalate (PET) in stone mastic asphalt. Constr. Build. Mater. 36, 984-989 (2012)

9. Moghaddam, T.B., Karim, M.R., Syammaun, T.: Dynamic properties of stone mastic asphalt mixtures containing waste plastic bottles. Constr. Build. Mater. 34, 236-242 (2012)

10. Binici, H., Gemci, R., Kaplan, H.: Physical and mechanical properties of mortars without cement. Constr. Build. Mater. 28(1), 357-361 (2012)

11. Yildirim, Y.: Polymer modified asphalt binders. Constr. Build. Mater. 21(1), 66-72 (2007)

12. Casey, D., McNally, C., Gibney, A., Gilchrist, M.D.: Development of a recycled polymer modified binder for use in stone mastic asphalt. Resour. Conserv. Recycl. 52(10), 1167-1174 (2008)

13. Yildirim, Y., Hazlett, D., Davio, R.: Toner-modified asphalt demonstration projects. Resour. Conserv. Recycl. 42(3), 295308 (2004)

14. Fang, C., Yu, R., Zhang, Y., Hu, J., Zhang, M., Mi, X.: Combined modification of asphalt with polyethylene packaging waste and organophilic montmorillonite. Polym. Test. 31(2), 276-281 (2012)

15. Ho, S., Church, R., Klassen, K., Law, B., MacLeod, D., Zanzotto, L.: Study of recycled polyethylene materials as asphalt modifiers. Can. J. Civ. Eng. 33(8), 968-981 (2006)

16. Dalhat, M.A., Wahhab, H.I.A.A.: Performance of recycled plastic waste modified asphalt binder in Saudi Arabia. Int. J. Pavement Eng. 18(4), 349-357 (2017)

17. Murphy, M., O’Mahony, M., Lycett, C., Jamieson, I.: Bitumens modified with recycled polymers. Mater. Struct. Constr. 33(7), 438-444 (2000)

18. Hassani, A., Ganjidoust, H., Maghanaki, A.A.: Use of plastic waste (poly-ethylene terephthalate) in asphalt concrete mixture as aggregate replacement. Waste Manag. Res. 23(4), 322-327 (2005)

19. Zoorob, S.E., Suparma, L.B.: Laboratory design and investigation of the properties of continuously graded Asphaltic concrete containing recycled plastics aggregate replacement (Plastiphalt). Cem. Concr. Compos. 22(4), 233-242 (2000)

20. Lenkiewicz, Z., Webster, M.: Making waste work : a toolkit how to measure your waste part of making waste work : a toolkit income countries (2017).

21. Tech Insider: Building houses out of plastic waste-YouTube (2016). https://www.youtube.com/watch? $\mathrm{v}=$ MXbrKQE-SOE. Accessed 24 Feb 2021.

22. UN Environment Programme: Plastic bricks in KenyaNZAMBI MATEE-Young Champion of the Earth 2020 for Africa - YouTube (2020). https://www.youtube.com/watch?v= QbZKP4UAtL8. Accessed 24 Feb 2021.
23. The Times of India: Indian homes and pavements made from plastic-BBC News-YouTube (2019). https://www.youtube. com/watch?v=icgzeSWo7C4. Accessed 24 Feb 2021.

24. CGTN Africa: Entrepreneur transforms plastic waste into construction materials-YouTube (2019). https://www.youtube. com/watch?v=yA0nGBSy6_I. Accessed 24 Feb 2021.

25. D. C. Wilson et al.: Global Waste Management Outlook. International Solid Waste Association (2015).

26. An, T., Huang, Y., Li, G., He, Z., Chen, J., Zhang, C.: Pollution profiles and health risk assessment of VOCs emitted during e-waste dismantling processes associated with different dismantling methods. Environ. Int. 73, 186-194 (2014)

27. Lerner, J.E.C., Sanchez, E.Y., Sambeth, J.E., Porta, A.A.: Characterization and health risk assessment of VOCs in occupational environments in Buenos Aires, Argentina. Atmos. Environ. 55, 440-447 (2012)

28. Sax, S.N., Bennett, D.H., Chillrud, S.N., Ross, J., Kinney, P.L., Spengler, J.D.: A cancer risk assessment of inner-city teenagers living in New York City and Los Angeles. Environ. Health Perspect. 114(10), 1558-1566 (2006)

29. He, Z., Li, G., Chen, J., Huang, Y., An, T., Zhang, C.: Pollution characteristics and health risk assessment of volatile organic compounds emitted from different plastic solid waste recycling workshops. Environ. Int. 77, 85-94 (2015)

30. Health and Safety Executive: EH40/2005 workplace exposure limits limits for use with the Control of Substances (Fourth Edition 2020) (2020).

31. Mitera, J., Michal, J., Kubát, J., Kubelka, V.: Analysis of thermo-oxidation products of polypropylene and polyethylene by Gas chromatography/mass spectrometry. Fresenius' Zeitschrift für Anal. Chemie 281(1), 23-27 (1976)

32. Andersson, T., Wesslén, B., Sandström, J.: Degradation of low density polyethylene during extrusion. I. Volatile compounds in smoke from extruded films. J. Appl. Polym. Sci. 86(7), 15801586 (2002)

33. Patel, S.H., Xanthos, M.: Volatile emissions during thermoplastics processing — a review. New Jerset (1995)

34. U. National Library of Medicine: PubChem (2021). https:// pubchem.ncbi.nlm.nih.gov/. Accessed 7 May 2021.

35. Kumi-Larbi, A., Yunana, D., Kamsouloum, P., Webster, M., Wilson, D.C., Cheeseman, C.: Recycling waste plastics in developing countries: use of low-density polyethylene water sachets to form plastic bonded sand blocks. Waste Manag. 80, 112-118 (2018)

36. Maneeth, P.D., Pramod, K., Kishor, K., Shanmukha, S.: Utilization of waste plastic in manufacturing of plastic-soil bricks. Int. J. Eng. Res. Technol. 2(4), 102-107 (2014)

37. Ashraf, A.: Thermal conductivity measurement by hot disk analyser (2016)

38. Uthaipan, N., Jarnthong, M., Peng, Z., Junhasavasdikul, B., Nakason, C., Thitithammawong, A.: Effects of cooling rates on crystallization behavior and melting characteristics of isotactic polypropylene as neat and in the TPVs EPDM/PP and EOC/PP. Polym. Test. 44, 101-111 (2015)

39. Goli, V.S.N.S., Mohammad, A., Singh, D.N.: Application of municipal plastic waste as a manmade neo-construction material: issues \& wayforward. Resour. Conserv. Recycl. 161, 105008 (2020)

40. Awaja, F., Gilbert, M., Kelly, G., Fox, B., Pigram, P.J.: Adhesion of polymers. Prog. Polym. Sci. 34(9), 948-968 (2009)

41. Zahran, R.R.: Effect of sand addition on the tensile properties of compression moulded sand/polyethylene composite system. Mater. Lett. 34(3-6), 161-167 (1998)

42. Verbeek, C.J.R., Pickering, K.L.: Recent developments in polymer consolidated composites. J. Reinf. Plast. Compos. 26(16), 1607-1624 (2007) 
43. Verbeek, C.J.R.: Effect of percolation on the mechanical properties of sand-filled polyethylene composites. J. Thermoplast. Compos. Mater. 20(2), 137-149 (2007)

44. Mehdipour, I., Khayat, K.H.: Effect of particle-size distribution and specific surface area of different binder systems on packing density and flow characteristics of cement paste, vol. 78 . Elsevier, New York (2017)

45. Dalhat, M.A., Wahhab, H.I.A.-A.: Cement-less and asphalt-less concrete bounded by recycled plastic. Constr. Build. Mater. 119, 206-214 (2016)

46. Mitchell, J., Vandeperre, L., Dvorak, R., Kosior, E., Tarverdi, K., Cheeseman, C.: Recycling disposable cups into paper plastic composites. Waste Manag. 34(11), 2113-2119 (2014)
47. Leon, L., Charles, R., Simpson, N.: Stress-strain behaviour of asphalt concrete in compression. Procedia Struct. Integr. 2, 2913-2920 (2016)

48. Iucolano, F., Liguori, B., Caputo, D., Colangelo, F., Cioffi, R.: Recycled plastic aggregate in mortars composition: effect on physical and mechanical properties. Mater. Des. 52, 916-922 (2013)

49. Hassn, A., Aboufoul, M., Wu, Y., Dawson, A., Garcia, A.: Effect of air voids content on thermal properties of asphalt mixtures. Constr. Build. Mater. 115, 327-335 (2016)

Publisher's Note Springer Nature remains neutral with regard to jurisdictional claims in published maps and institutional affiliations. 